\title{
KDM4B: A Nail for Every Hammer?
}

\author{
Cailin Wilson ${ }^{1}$ and Adam J. Krieg ${ }^{2,3, *(\mathbb{C}}$ \\ 1 Department of Pathology, University of Kansas Medical Center, Kansas City, KS 66160, USA; \\ cailin.wilson@gmail.com \\ 2 Department of Obstetrics and Gynecology, Oregon Health and Science University, Portland, OR 97239, USA \\ 3 Division of Reproductive and Developmental Sciences, Oregon National Primate Research Center, \\ Beaverton, OR 97006, USA \\ * Correspondence: kriega@ohsu.edu; Tel.: +1-(503)-346-5367
}

Received: 21 December 2018; Accepted: 7 February 2019; Published: 12 February 2019

\begin{abstract}
Epigenetic changes are well-established contributors to cancer progression and normal developmental processes. The reversible modification of histones plays a central role in regulating the nuclear processes of gene transcription, DNA replication, and DNA repair. The KDM4 family of Jumonj domain histone demethylases specifically target di- and tri-methylated lysine 9 on histone $\mathrm{H} 3$ (H3K9me3), removing a modification central to defining heterochromatin and gene repression. KDM4 enzymes are generally over-expressed in cancers, making them compelling targets for study and therapeutic inhibition. One of these family members, KDM4B, is especially interesting due to its regulation by multiple cellular stimuli, including DNA damage, steroid hormones, and hypoxia. In this review, we discuss what is known about the regulation of KDM4B in response to the cellular environment, and how this context-dependent expression may be translated into specific biological consequences in cancer and reproductive biology.
\end{abstract}

Keywords: histone demethylases; KDM4B; hypoxia; cancer; development; ovary

\section{Introduction}

Once thought to be too chemically stable to be enzymatically reversed, methyllysine residues are now recognized as dynamic components of the histone code [1,2]. The characterization of LSD1 (KDM1A) as the first histone demethylase in 2004 was quickly followed by the discovery that the Jumonji-domain family of genes constitutes a diverse group of histone demethylases capable of reversing many of the known methyllysine residues in histones [3-6]. The founding gene Jumonji, named for the cruciform neural plate defect caused by genetic deletion in mice, contains a domain similar to the transcriptional co-repressor RBP2 (now known as JARID1A) [7,8]. By sequence comparison, this C-terminal portion of the Jumonji domain $(\mathrm{JmjC})$ was shown to be a member of the large and diverse superfamily of non-heme iron-dependent dioxygenases [8,9]. Currently, there are 30 proteins classified by their JmjC-domain in humans [9]. Of these, 22 act as lysine specific histone demethylases (KDMs) [10].

Similar to other dioxygenases, the basic protein structure of the JmjC domain is a $\beta$ sheet "jelly roll" with iron II $\left(\mathrm{Fe}^{2+}\right)$ coordinated in the central active site [8]. The majority of JmjC proteins use 2-oxoglutarate (2-OG, or $\alpha$-ketoglutarate) and molecular oxygen $\left(\mathrm{O}_{2}\right)$ as substrates to hydroxylate methyllysines in the $\mathrm{N}$-terminal tails of histones, with $\mathrm{CO}_{2}$ and succinate as products. The resulting hydroxy-methyllysine is chemically unstable and rapidly degrades to formaldehyde and a lysine with a reduced level of methylation. The JmjC domain is frequently accompanied by an $\mathrm{N}$-terminal domain $(\mathrm{JmjN})$ that may contribute to substrate specificity and regulatory function [11,12]. When grouped by similarity of the JmjC domains and flanking sequences, there are six subfamilies of JmjC- KDMs (KDM2-KDM7), multiple histone demethylases not yet classified into distinct families 
(MINA53, NO66, KDM8), with the remaining members of the family hydroxylating non-histone substrates (JMJD6 and HIF1AN) or with uncharacterized catalytic activity (HSBAP1, JMJD7, JMJD8). The founding member of the JmjC family, now known as JARID2, lacks the key histidine and aspartate residues necessary to coordinate $\mathrm{Fe}^{2+}$ yet functions as a co-repressor in the polycomb silencing complex [13-15]. For a more comprehensive survey of the various JmjC-KDMs, we direct the reader to several excellent reviews $[1,9,10]$. For the purpose of this review, we will focus on KDM4B, a member of the KDM4/JMJD2B histone demethylase family notable for its diverse expression patterns in several tissues and pathological states.

\section{KDMB is a Histone Demethylase that Reverses Repressive Histone Modifications}

KDM4B is a member of the KDM4/JMJD2 family of histone demethylases. The KDM4 family contains four genes (KDM4A-KDM4D) and two pseudogenes (KDM4E and KDM4F) (Figure 1). $\mathrm{KDM} 4 \mathrm{~A}, \mathrm{KDM} 4 \mathrm{~B}$, and $\mathrm{KDM} 4 \mathrm{C}$ are very similar in overall protein structure, each containing a JmjN domain, JmjC domain, two Plant Homeodomains (PHD), and two Tudor domains. KDM4D and KDM4E are smaller and lack the C-terminal PHD and Tudor domains $[5,16,17]$. The JmjC domain facilitates catalytic activity for these proteins while the JmjN domain may serve as a dimerization domain and provide structural integrity [5,16-18]. KDM4B localizes to the human chromosome 19p13.3 [16]. The full-length KDM4B protein is 1096 amino acids in length with catalytic activity against the histone residues H3K9me3, H3K9me2, H3K36me3, H3K36me2, H4K20me2, and H1.4K26me3, although H3K9me2/3 is the preferred substrate $[16,19,20]$. Like the rest of the KDM4 family, KDM4B can demethylate tri- and di-methyllysine to the monomethyl state [21,22]. Although the majority of epigenetics literature associates di- and tri- methylation of $\mathrm{H} 3 \mathrm{~K} 9$ with heterochromatin and gene repression [23-28], there is also evidence that H3K9 methylation located within gene bodies serves to facilitate gene expression [29,30]. Furthermore, the degree of H3K9 methylation correlates with nuclear position of chromatin, with $\mathrm{H} 3 \mathrm{~K} 9 \mathrm{me} 1$ associated with open transcribed chromatin, H3K9me2 associated with nuclear lamina, and H3K9me3 corresponding to condensed chromatin [31-33]. KDM4B induction in specific contexts would then be predicted to remodel nuclear localization and transcriptional activity of specific gene regions by demethylating $\mathrm{H} 3 \mathrm{~K} 9 \mathrm{me} 2 / 3$.

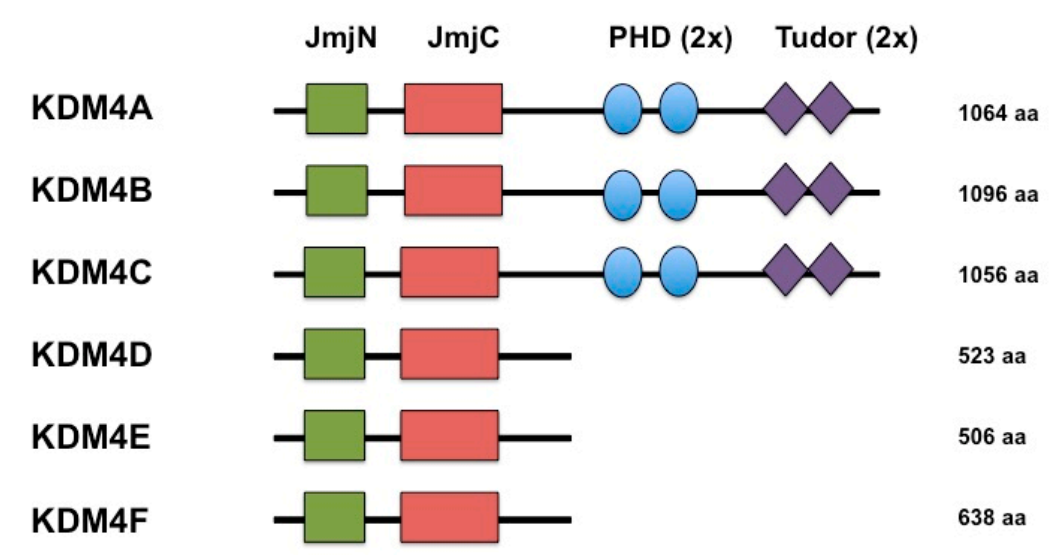

Figure 1. Diagram of the comparative domain structures of the KDM4 histone demethylases (adapted from Katoh and Katoh, 2004).

In general, loss of one KDM4 family member is not sufficient to distort total histone methylation, suggesting that each family member regulates a specific set of genes in a specific cell type or condition [23,34-36]. ChIP-Seq mapping of Kdm4b and Kdm4c in murine embryonic stem cells showed that regions bound by $\mathrm{Kdm} 4 \mathrm{~b}$ alone or in combination with $\mathrm{Kdm} 4 \mathrm{c}$ were largely associated with transcriptionally active genes, while sites bound by $\mathrm{Kdm} 4 \mathrm{c}$ alone were associated with repressed regions [34]. In contrast to other studies [37], loss of $\mathrm{Kdm} 4 \mathrm{~b}$ or $\mathrm{Kdm} 4 \mathrm{c}$ was not associated with promoter-specific changes in $\mathrm{H} 3 \mathrm{~K} 9 \mathrm{me} 3$ [34]. Further research is required to determine if genes induced 
by loss of KDM4B are the result of direct repression or indirect loss of a repressor positively regulated by KDM4B [34,36,38]. Non-histone substrates have also been identified for KDM4A-C [39]. All three enzymes demethylate the transcriptional repressors WIZ (ZNF803), CSB (ERCC6), CDYL1, and G9a (EHMT2) with higher specific activities than for methylated H3K9me3 peptides [39]. In the case of KDM4B, the majority of its function is associated with the activation or maintenance of gene expression, implying that its demethylase activity serves primarily to reverse histone marks that repress expression of KDM4B target genes [40].

A great deal of what is known regarding the other protein domains in KDM4B has been inferred from KDM4A function: The Tudor domains of KDM4A recognize H3K4me3/me2 and H4K20me3/me2 [41]. KDM4B tends to have lower affinity for H3K4me3 and other marks in vitro [42], but has been shown to be recruited to H4K20me3/2 at sites of DNA damage [43]. More recently, the Tudor domains of KDM4B have been shown to bind to H3K23me2/3, potentially recruiting KDM4B to meiotic heterochromatin in order to more efficiently demethylate H3K36me3 [42]. This differential recognition of specific histone marks by the Tudor domains of the KDM4 family may enable preferential recruitment to chromatin domains, targeting histone demethylation events to specific regions, and thereby influencing biological phenomena. The complexity of the KDM4B molecule, its variable catalytic and binding activities, and diverse expression mechanisms make it a flexible regulator of chromatin structure and biological processes.

\section{KDM4B is Regulated by Multiple Cellular Stimuli}

A key aspect of mediating the function of KDM4B (or any protein) is regulating the overall expression levels of said protein. While KDM4A is one of the best-studied JmjC-KDMs at the level of catalytic mechanism and structural analysis, KDM4B has tended to receive more attention at the level of transcriptional regulation and downstream function [40]. In particular, KDM4B is regulated by hypoxia, steroid hormone receptors, DNA damage, and multiple other cellular stimuli. These expression phenomena may work in isolation or in concert to tune the cellular response (Figure 2).

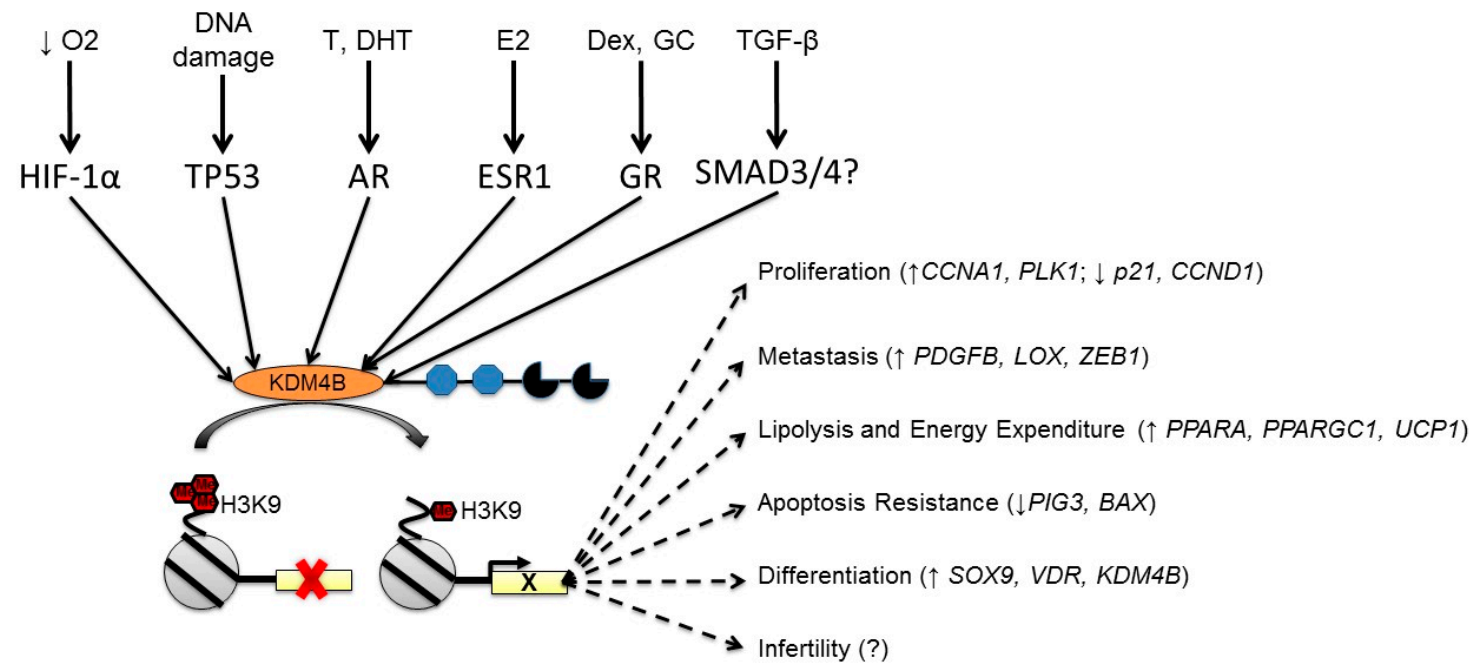

Figure 2. KDM4B integrates multiple cellular signals to affect biological processes. KDM4B is induced by multiple different extracellular stimuli. The majority of studies regarding its function describe it as an activator that removes repressive $\mathrm{H} 3 \mathrm{~K} 9 \mathrm{me} 3$ and $\mathrm{H} 3 \mathrm{~K} 9 \mathrm{me} 2$ at or near regulated promoters in order to facilitate expression of the indicated pathways. Representative target genes (if known) are shown in each pathway.

\subsection{Regulation of KDM4B by Hypoxia}

Shortly after the discovery of JmjC-KDMs, multiple reports demonstrated the hypoxic regulation of several histone demethylases [44-46]. Given the strong link between tumor hypoxia and poor 
patient outcome, these discoveries made compelling links between the cellular microenvironment, epigenetic regulation, and tumor progression [47]. Hypoxia drives tumorigenic changes within cells and it also selects for cells equipped to survive fluctuations in oxygen availability [48]. Hypoxia occurs in cells approximately 100-200 $\mu \mathrm{m}$ away from a functional blood supply and at sites of heterogeneous tumor blood flow $[49,50]$. Tumor hypoxia is associated with therapeutic resistance driven by increased metastatic behavior, increased angiogenesis, reduced proliferation, increased glycolysis, and resistance to apoptosis [51-53]. All of these pathways contribute to therapeutic resistance, and many genes that constitute these pathways are directly regulated at the transcriptional level by Hypoxia Inducible Factors (HIFs) [53].

The HIFs are heterodimeric basic helix-loop-helix transcription factors that directly regulate the expression of hundreds of genes required for adaptation to hypoxia [54-56]. The primary mode of regulation for these proteins is oxygen-dependent degradation of the $\alpha$ subunit (HIF- $1 \alpha$ and HIF-2 $\alpha$ ) mediated by prolylhydroxylases (PHDs) $[57,58]$. When sufficient oxygen and 2-OG is available, PHDs hydroxylate prolines 402 and 564 of HIF- $1 \alpha$ and prolines 405 and 531 of HIF-2 $\alpha$ [59-61]. The conformation shift imposed by the 4-hydroxyprolines creates a recognition motif for the Von Hippel Lindau tumor suppressor (VHL), an E3 ubiquitin ligase that promotes degradation of HIFs through the proteasome [62-64]. Reduction of $\mathrm{O}_{2}$ or 2-OG in the hypoxic microenvironment permits the rapid accumulation of HIF- $1 \alpha$ and HIF- $2 \alpha$, their subsequent dimerization with the Arylhydrocarbon nuclear translocator (ARNT or HIF-1 $\beta$ ), and binding to Hypoxia-responsive elements (HREs) in the promoters of hypoxia-inducible genes [65,66]. KDM4B is directly induced by HIF-1 $\alpha$ from an HRE located approximately $500 \mathrm{bp}$ upstream of the transcriptional start site [44-46,67]. The hypoxic induction of KDM4B in multiple cell types makes it a particularly compelling target for studying epigenetic regulatory mechanisms in various cancers.

The regulation of KDM4B by hypoxia raises interesting questions regarding its downstream effects on gene expression. Because all JmjC enzymes require oxygen for their catalytic activity, it is tempting to hypothesize that hypoxic induction of KDM4B serves to compensate for reduced substrate availability. However, in one of the earliest descriptions of the hypoxic regulation of KDM3A and KDM4B, Beyer et al. demonstrated that while both KDM3A and KDM4B were functional histone demethylases in $1 \% \mathrm{O}_{2}$, only KDM3A was functional in $0.2 \% \mathrm{O}_{2}$ [44]. More recently, $\mathrm{KDM} 4 \mathrm{~A}$ was shown to have an apparent $\mathrm{Km}\left(\mathrm{O}_{2}\right)$ of $176 \mu \mathrm{M}$ (roughly equivalent to $18 \% \mathrm{O}_{2}$ at $37^{\circ} \mathrm{C}$ ), indicating that catalytic activity of KDM4 enzymes is highly sensitive to changes in cellular oxygen [68]. At $1 \% \mathrm{O}_{2}$, KDM4A was $40 \%$ less effective as a histone demethylase than at $21 \%$, and had virtually no activity at $0.1 \%$ [68]. KDM4 enzymes are less sensitive to $\mathrm{O}_{2}$ changes compared to the prolyl hydroxylases, which have $\mathrm{Km}\left(\mathrm{O}_{2}\right)$ ranging from 230-450 uM, depending on the study [69,70]. In this respect, the KDM4 family may be more similar to FIH (Factor Inhibiting HIF), another JmjC domain protein with glutamine hydroxylase activity $\left(\mathrm{Km}\left(\mathrm{O}_{2}\right)\right.$ of 90-110 $\left.\mathrm{mM}\right)[69,70]$. The histone demethylase activity of KDM4B will likely attenuate significantly within a hypoxic microenvironment. Nevertheless, siRNA-mediated knockdown of KDM4B in MCF7 and SKOV3ip.1 cells demonstrate that loss of KDM4B in hypoxic conditions has profound effects on downstream gene expression, and that many of the genes regulated under standard oxygen are distinctly different from those regulated by hypoxia [35,36]. Furthermore, while the genes positively regulated by KDM4B under hypoxia included a subset of HIF targets, glycolytic genes were not generally altered, implying that KDM4B is not a general co-regulator for HIFs [35]. When interpreted in light of recent reports that Kdm4b positively regulates lipolysis and mitochondrial energy expenditure, it appears that KDM4B contributes more to aerobic metabolism than anaerobic metabolism [71,72].

Combined with evidence of reduced catalytic activity in hypoxia [44], it remains to be determined if induction of KDM4B regulates hypoxic gene expression solely through histone demethylation, or if it also can play a structural role in nucleating larger transcriptional complexes, as in the case of JARID2 [13,14]. The association of Kdm4b with Myc- and Nanog-regulated promoters in the apparent absence of $\mathrm{H} 3 \mathrm{~K} 9 \mathrm{me} 3$ changes supports this possibility [34]. Additionally, hypoxic induction of KDM4B 
might load a regulatory region with histone demethylases under hypoxic conditions, leaving it "poised" to demethylate histones once oxygen is restored. Because hypoxic induction of KDM4B is observed in many cell types, there remain ample opportunities to investigate the specific mechanisms of gene expression and DNA repair regulated by KDM4B in hypoxia.

\subsection{Regulation of KDM4B by Nuclear Hormone Receptors}

In one of the earliest characterizations of KDM4B function, Yang et al. convincingly demonstrated that KDM4B was induced by both HIF-1 $\alpha$ and estrogen receptor $\alpha$ (ESR1) in MCF7 breast cancer cells [36]. Experiments using human cancer cells and knockout mouse models demonstrated a role for KDM4B as an essential factor for estrogen-dependent gene expression and for growth and differentiation of the mammary epithelium [73,74]. This establishes KDM4B as a significant contributor to estrogen-dependent gene expression; in response to estrogen, KDM4B is induced, and the resulting protein binds the promoters of some estrogen regulated genes, regulating both itself, ESR1, FOXA1, and genes that regulate proliferation of breast cancer [75]. Since many of the estrogen-induced genes that regulate breast cancer proliferation and progression are also regulated by hypoxia (Cyclin D1, WISP2, etc.), KDM4B serves to integrate two known drivers of breast cancer progression [40]. Effectively targeting KDM4B in ER+ breast cancer patients could prevent Tamoxifen resistance by preventing re-expression through hypoxic signaling. Although less well studied, there are indications that glucocorticoid receptors enhance the ESR1-dependent induction of KDM4B in breast cancer [76]. In this case, breast cancer cells have a more differentiated phenotype, inducing expression of KDM4B and VDR while preventing expression of Wnt-signaling molecules [76].

KDM4B expression is also directly induced by androgens via the androgen receptor to promote a more aggressive prostate cancer phenotype [77,78]. In prostate cancer cells, KDM4B expression, which correlates with the severity of tumor types, can cooperate with $A R$ to induce the $A R$ response [77]. KDM4B also stabilizes AR through inhibiting its ubiquitination and degradation [77]. Knockdown of KDM4B results in decreased AR expression [77]. The progression of prostate cancer from androgen-dependent to androgen-independent is one characteristic of this disease's lethal progression [79]. These observations suggest that KDM4B may be a useful therapeutic target in prostate cancer for both androgen-dependent and androgen-independent tumor types [80]. Inhibition of KMD4B in combination with other chemotherapeutic drugs may improve current treatment options for prostate cancer.

\subsection{Regulation of KDM4B by DNA Damage}

In addition to being induced by pro-tumorigenic regulatory mechanisms, KDM4B has also been shown to be induced by the tumor suppressor p53 [38,81]. When activated by DNA damage or the chemical inducer nutlin, p53 directly binds the p53RE located approximately $500 \mathrm{bp}$ upstream of the KDM4B transcriptional start site [38]. This mode of regulation may be specific to humans and other non-human primates: Murine cells do not induce $\mathrm{Kdm} 4 \mathrm{~b}$ following DNA damage, and expression is not altered in p53 knock-out MEFs [38]. This is in contrast to the hypoxic induction of KDM4B in human and murine cells $[44,45,67]$, as well as the estrogen-dependent induction of KDM4B in both breast cancer and murine mammary epithelium [36,74]. The functional consequences of this p53-dependent regulation remain to be completely determined, but in three independent manuscripts, loss of KDM4B increases the baseline expression of the p21 cell cycle inhibitor (CDKN1A), PIG3, and PUMA $[38,81,82]$. In a more comprehensive analysis, Castellini et al. demonstrated that KDM4B may act as a negative feedback regulator of p53 target gene expression, and that loss of KDM4B more effectively inhibited tumor growth in parental HCT116 cells compared to matched p53-KO cells [38]. Loss of KDM4B may also activate p53 in gastric cancer cells, resulting in increased expression of p21 and reduced proliferation [82].

Induction of KDM4B by DNA damage may facilitate DNA repair by decreasing levels of H3K9me3 in pericentric chromatin [81]. Simultaneous downregulation of SUV39H1 by p53 further reinforces the 
demethylation process [81]. In a separate study, KDM4A and KDM4B were both shown to localize to H4K20me2 in response to DNA damage [43]. This localization slowed recruitment of 53BP1 to sites of damage and was reversed by ubiquitylation of KDM4A/B by RNF8 (Figure 3). While Mallete et al. concluded that slowing 53BP1 recruitment would increase DNA damage [43], one could also speculate that blocking 53BP1 recruitment could slow non-homologous end-joining (NHEJ). In non-transformed cells, this could increase the efficiency of homologous recombination and other higher fidelity mechanisms, resulting in reduced genomic dysregulation [83]. A role for KDM4B has been proposed in the transient amplification of chromosome 1p32.3 during replication, a possible mechanism of generating DNA damage [84]. KDM4B was shown to directly interact with replication factors and components of the DNA polymerase complex directing selective re-replication of $1 \mathrm{p} 32.3$ [84]. This mechanism appears to be similar to the site-specific amplification of chromosome 1 (1q12h, 1q21.2, 1q21.3) mediated by KDM4A in hypoxia and during DNA replication [84-86]. Overexpression of KDM4B has also been shown to induce DNA damage by activating LINE-1 elements [87]. How these effects of KDM4B expression integrate with the induction of KDM4B by other stressors remains to be determined.

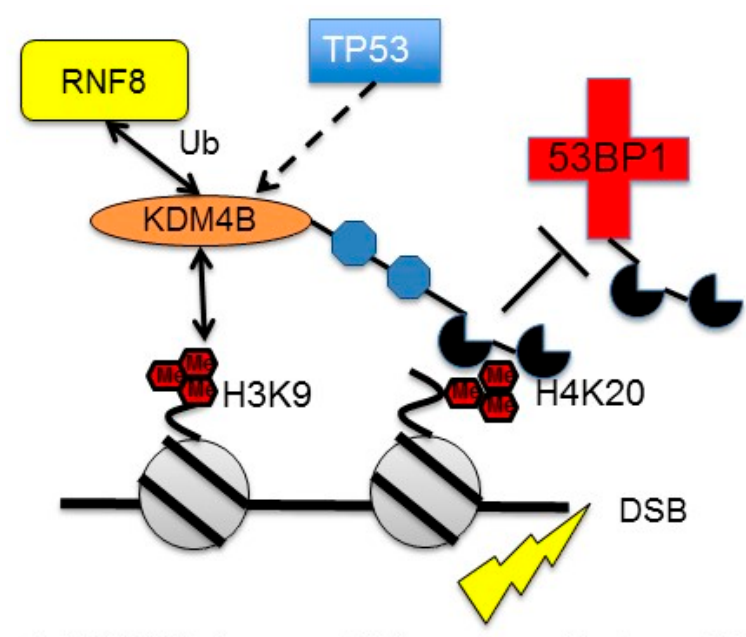

Figure 3. KDM4B influences DNA repair mechanisms. KDM4B is directly induced by p53. The Tandem Tudor domains target KDM4B to H4K20me3/2 at sites of DNA damage. This recruitment blocks the binding of 53BP1 to the same marks until RNF8 removes KDM4B through ubiquitylation. KDM4B can also be recruited to heterochromatin in response to DNA damage, removing H3K9me3/2 to facilitate DNA repair. (Adapted from Young et al., 2013, Mallette et al., 2012 and Zheng et al., 2013).

The regulation of KDM4B by p53 has primarily been observed in transformed cells expressing wild-type p53 (i.e. HCT116 colon carcinoma, U2OS osteosarcoma cells, and gastric cancer cells) [38,81,82]. It remains to be determined if non-transformed cells display this same mechanism of regulation. Nevertheless, several testable hypotheses can be proposed: Does hypoxic and hormone-dependent regulation of KDM4B attenuate the cell cycle arrest and apoptosis functions of p53 sufficiently to permit transformation and sustain tumorigenesis? In non-transformed cells, does suppression of KDM4B drive cell cycle arrest and senescence sufficiently to prevent tumorigenesis? Could KDM4B induction by $\mathrm{p} 53$ represent another facet of DNA repair regulated by p53? How does DNA damage induced by over-expression of KDM4B in some models fit into its regulation by p53? The absence of p53-dependent regulation in murine cells makes it more difficult to construct a genetically tractable model to test these hypotheses. Continued interest in KDM4B will also doubtless identify other modes of regulation, such as induction by CREB and TGF- $\beta$ [88,89]. Future experiments are required to reconcile these pieces of data in a manner reflective of the conditional nature of KDM4B expression and the effect of cell background. 


\section{Integrating KDM4B Expression Phenomena with Biological Processes}

\subsection{KDM4B and Stem Cell Biology}

Epigenetic modifiers are important contributors to developmental processes [90], and KDM4B is no exception. KDM4B is expressed in undifferentiated and differentiated ESCs [91]. ESCs are indefinitely self-renewing and differentiating cell populations, with identities maintained or differentiation controlled by activation of specific genes through transcription factors or chromatin regulators [34,90,92]. Kdm4b participates in embryonic stem cell self-renewal and induced pluripotent stem cell generation in mouse models by associating with Nanog-regulated promoters [34]. Kdm4b and Kdm4c work synergistically to mediate gene expression during differentiation of mouse ESCs [34]. H3K9me3 marks in heterochromatin are very stable and resist reprogramming. Thus, reduction of H3K9me3 levels by Kdm4b improved in vitro development of cloned embryos [93]. Ectopic introduction of KDM4D to somatic cell nuclear transfer experiments has resulted in more efficient cloning of macaque embryos [94]. There is evidence that $\mathrm{Kdm} 4 \mathrm{~b}$ and $\mathrm{Km} 4 \mathrm{~d}$ may have overlapping and compensatory roles in spermatogenesis [95]. Future investigations into KDM4B and KDMD function during gametogenesis should determine the specific mechanisms regulated by each enzyme to remodel chromatin during gametogenesis and embryogenesis.

\subsection{KDM4B and Mesenchymal Tissues}

KDM4B regulates mesenchymal stem cell (MSC) fate, identifying a possible control mechanism to exploit in directing MSC lineage [96,97]. MSCs are multipotent progenitor cells with multi-lineage differentiation potential [96]. KDM4B controls MSC differentiation and fate by removing H3K9me3 to activate DLX [96,97]. Loss of KDM4B reduced osteogenic differentiation and increased adipogenic differentiation $[96,97]$. BMP4 induces DLX5 and KDM4B in stem cells of the apical papillae to mediate osteo-dental differentiation [98]. Regulation of KDM4B by SMADS and DLX5 establishes a positive feedback mechanism to maintain expression of DLX5 [98]. This provides a promising therapeutic target for diseases such as osteoporosis, which are commonly associated with a loss of MSC commitment [96,97].

KDM4B participates in chondrogenesis and adipogenesis in MSCs $[89,99]$. TGF- $\beta$ dependent KDM4B expression removes the repressive H3K9me3 mark from the SOX9 promoter, inducing expression of one of the master regulators of chondrogenesis [89]. In adipogenesis, KDM4B binds $\mathrm{C} / \mathrm{EBP} \beta$ (CCAAT/enhancer-binding protein) to promote mitotic clonal expansion, an important process preadipocytes enter as they differentiate $[99,100]$. KDM4B binds C/EBP $\beta$, demethylates H3K9me3 to regulate expression of cell cycle genes CDC45I, MCM3, and CDC25C and to drive mitotic clonal expansion [99]. Although there were some differences between the respective models, knocking out $K d m 4 b$ in adipose tissue generally resulted in increased obesity, with increased expression of adipogenesis genes (e.g., Pparg2 and $a P 2$ ) and reduced expression of genes in energy expenditure and lipolysis pathways (e.g., Ppargca1, Ppara, Acox1, and Atgl) [71,72]. Re-expression of Kdm4b in $\mathrm{Kd} m 4 b-\mathrm{KO}$ adipocytes required a functional demethylase domain to restore energy expenditure and cellular oxygen consumption, demonstrating that removal of $\mathrm{H} 3 \mathrm{~K} 9$ me was required for target gene expression [72]. If KDM4B also regulates adipose differentiation in humans, selectively increasing expression in adipose tissue could help treat obesity.

\subsection{KDM4B in the Central Nervous System}

In addition to stem cell maintenance and differentiation, KDM4B is involved in neurobiological processes. KDM4B is a critical component in development of the central nervous system (CNS) [101]. Neuron-specific KDM4B knockout mice displayed neurodevelopmental disorders including spinal malformations and hippocampal impairment [101]. The hippocampus exhibited hyperactive behavior, deficits in working memory, and spontaneous epileptic seizures [101]. This $K d m 4 b$ knockout model provides a novel system for neurodevelopmental disorder in vivo investigations [101]. 


\subsection{KDM4B in Ear Development}

In addition to CNS development, KDM4B regulates inner ear invagination and ear development [102]. KDM4B is expressed during early stages of chick inner ear formation and loss of expression results in defective otic placode invagination and morphological changes [102]. KDM4B regulates DLX3, a marker for inner ear, by demethylating H3K9me3 in its promoter region [102]. This study provides one of the first connections between a histone demethylase and ear development.

\subsection{KDM4B in Reproductive Tissues}

KDM4B is linked to spermatogenesis and mammary gland development [74,103]. Increased $\mathrm{Kdm} 4 \mathrm{~b}$ and decreased H3K9me3 were observed during pre-spermatogenesis [103]. This suggests a role for KDM4B in reorganization of constitutive heterochromatin during a period of a key step of gametogenesis [103]. Kdm4b binds to estrogen receptor to regulate mammary gland development [74]. A mammary-epithelium specific conditional $K d m 4 b$ knockout mouse results in defective mammary gland development, identifying KDM4B as an important epigenetic component [74].

In the course of studying KDM4B in ovarian cancer, Wilson and Qiu et al. conducted control studies to detect KDM4B in normal ovarian tissue [35]. While ovarian surface epithelium showed little to no expression of KDM4B, there was robust expression in primordial follicles [35]. In follow up studies using archival ovarian cross-sections and granulosa cells collected from in vitro fertilization experiments, KDM4B and KDM4A mRNA was negatively correlated to successful pregnancy in IVF patients [104]. This was true for both the cumulus granulosa cells (the cells immediately adjacent to the oocyte in the developing follicle), and the mural granulosa (the cells lining the outside periphery of the follicle). Since granulosa cells are the primary producers of estrogen in the developing follicle, high expression of KDM4B would seem to be expected [105]. However, the strongest expression of KDM4B protein appeared to be in the early stages of folliculogenesis (i.e. primordial, primary, and secondary follicles) not in the later, antral stages [104]. It is not clear if this expression indicates that small follicles exist in a state of physiological hypoxia, if elevated $K D M 4 A$ and $K D M 4 B$ represents release of immature oocytes and granulosa during IVF, or if expression represents regulation by other stimuli.

$K D M 4 B$ mRNA is also elevated in the decidualized endometrial stroma of women with Recurrent Pregnancy Loss, compared to idiopathic miscarriage patients [106]. It is not clear if uterine KDM4B expression during miscarriage is related to its role in regulating the progression of endometrial cancer [107]. The expression of $K D M 4 B$ in the ovary and uterus provides fertile ground for understanding the intersection between steroid hormones, hypoxic signaling, and DNA damage pathways in the Reproductive Endocrinology and Infertility field, with significant potential to impact egg quality and embryo development.

\subsection{KDM4B in Non-Mammalian Systems}

In addition to mammalian systems, KDM4B has been implicated in regulating Drosophila development [108,109]. KDM4B is essential for mediating ecdysteroid hormone signaling during Drosophila larval development [108]. KDM4A and KDM4B demethylate H3K9me3 specifically at the promoter of genes responsive to ecdysone signaling, such as Broad Complex (BR-C), allowing increased expression [108]. Double knockout of Drosophila KDM4A and KDM4B results in developmental arrest [108]. Rescuing these double knockouts with expression of either KDM4A or KDM4B demonstrates that at least one of these proteins are essential for Drosophila development and survival [108].

\section{KDM4B in Cancer}

In addition to developmental processes, KDM4B has been shown to play a significant role in cancer progression. In general, when the activity and expression levels of histone demethylases are disrupted, neoplasms may form [110]. Many histone demethylases are deregulated during pathogenesis, either activating expression of oncogenes, repressing expression of tumor suppressors, altering DNA 
repair, disrupting chromosomal stability or interacting with key hormonal receptors that control proliferation [111]. The correlation between increased histone demethylase expression and tumor development has been established for many enzymes, such as LSD1 and KDM4C [112]. Optimizing inhibitors to specifically target JmjC containing KDMs have become a novel facet of therapy design [113]. Recent bodies of work have characterized the contributions of KDM4B to tumorigenesis in both solid and hematological tumor types $[40,114]$. In the following sections, we will attempt to synthesize what is known regarding the context-dependent expression of KDM4B as a mediator of tumor progression in multiple cancer types.

\subsection{KDM4B in Breast Cancer}

As discussed previously, KDM4B is induced by estrogen, making it important for progression of ER+ breast cancers [36,73-75]. The involvement of KDM4B in breast cancer has a clear contribution to the aggressive nature of the disease in ER+ subtypes [74]. KDM4B is highly expressed in estrogen receptor (ER)-positive, aggressive subtypes $[36,45,74]$. As discussed earlier in this review, the regulation of KDM4B by Glucocorticoid receptor (GR) and ER- $\alpha$ establishes a feed-forward mechanism to enhance estrogen-dependent signaling and proliferation in vitro and in vivo [76]. KDM4B is required for $\mathrm{ER} \alpha$ dependent transcription, where loss of KDM4B decreases cell proliferation in vitro and tumor progression in vivo $[36,73,76]$. KDM4B may also coordinate with additional epigenetic regulators to regulate histone modifications. KDM4B can bind ER- $\alpha$ and MLL2 to coordinate demethylation and methylation of H3K4 and H3K9 [73]. KDM4B and ER- $\alpha$ can also bind SWI-SNF-B remodeling complex to mediate the expression of ER responsive genes, $M Y B, M Y C$, and CCND1 [74]. The tumor suppressor miR-491-5p can bind KDM4B mRNA and slow ER- $\alpha+$ breast cancer development [115]. FBXO22, a subunit of the SCF ubiquitylation complex, degrades KDM4B when complexed to ESR1 in the unliganded or Tamoxifen-bound states [116]. Inhibiting degradation of KDM4B by blocking FBXO22 increases transcription mediated by the hormone-independent AF1 domain of ESR1 [116]. Targeting KDM4B or its regulated pathways in ER+ breast cancer may enhance the actions of Selective Estrogen Receptor Modulators to prevent tumor growth and recurrence. Targeting KDM4B with the demethylase inhibitors Methylstat or ML-324 activates the Unfolded Protein Response in PTEN-negative Triple-negative Breast Cancer (TNBC), an aggressive and hormone-independent form of breast cancer, sensitizing these cells to PI3-Kinase inhibitors [117]. Thus, KDM4B may function as a therapeutic target for both ER+ and ER- breast cancers.

\subsection{KDM4B in Prostate Cancer}

In addition to cooperating with $\mathrm{AR}$ to promote androgen-dependent gene expression and tumor progression [77], KDM4B promotes prostate cancer development through an AR-independent mechanism. KDM4B activates the transcription of BMYB-target genes important for cell-cycle progression and tumorigenesis, such as Polo-like kinase 1 (PLK1) [80]. KDM4B expression interferes with HDAC inhibitor efficacy. When $K D M 4 B$ was knocked out, the HDAC inhibitor trichostatin A (TSA) treatment enhanced induction of apoptosis [80]. These studies provide support for targeting KDM4B or its regulated pathways in prostate cancer.

\subsection{KDM4B in Colorectal Cancer}

KDM4B is highly expressed and is a known contributor to colorectal cancer (CRC) [118]. In addition to being regulated by HIF- $1 \alpha$ in this model, KDM4B can act as an oncogene and induce tumorigenesis through a variety of mechanisms [44]. When induced by PRL-3 a gene linked to $\mathrm{CRC}$ metastasis, KDM4B can promote CRC tumorigenesis by promoting proliferation, colony formation and migration of human colorectal cancer cells [118]. Silencing KDM4B induced DNA damage and triggered senescence, apoptosis, and cell cycle arrest through suppression of STAT3 signaling [119]. Recently, KDM4B was shown to be induced by CREB to suppress the DNA damage response mediated by STAT3 [88]. In addition, KDM4B suppression can drive CRC apoptosis through 
mitochondria-mediated and death receptor-mediated pathways [107]. KDM4B, in conjunction with TC4 also binds with $\beta$-catenin to regulate expression of the oncoproteins JUN, MYC, and Cyclin D1 [120]. This significant role of KDM4B in regulating many aspects of CRC suggests that it could make a useful therapeutic target.

\subsection{KDM4B in Gastric Cancer}

KDM4B is connected to gastric cancer carcinogenesis, lending itself as a possible novel biomarker or target for inhibition. Increased expression of KDM4B has been shown to drive gastric cancer proliferation, promote epithelial-mesenchymal transitions, and induce COX-2 dependent inflammation [121-123]. Similar to colorectal cancer, KDM4B functions in a complex with $\beta$-catenin to increase expression of genes involved in the epithelial-mesenchymal transition in a demethylase-dependent manner [124]. KDM4B can induce Helicobacter pylori infection and resulting gastric inflammation, one of the strongest risk factors for gastric cancer development [121]. $\beta$-catenin stimulates KDM4B expression that induces COX-2 expression in a histone demethylase-dependent manner [121]. KDM4B-dependent expression of miR-125b was recently shown to induce b-catenin nuclear translocation and promote gastric cancer metastasis [125]. These mechanisms establish KDM4B as a significant participant in gastric cancer.

\subsection{KDM4B in Osteosarcoma}

KDM4B has been connected to osteosarcoma tumorigenesis, a cancer type that effects young adults and is plagued with recurrence $[80,126]$. KDM4B expression has been shown to drive tumorigenesis and participate in the DNA damage response [80]. KDM4B can promote proliferation, migration, and invasion through induction of Fibroblast growth factor 2 (FGF2) [80]. Hsp90 has also been shown to stabilize KDM4B in osteosarcoma cell models, identifying Hsp90 inhibitors as a possible target for KDM4B driving tumor types [127]. KDM4B also participates in regulating the DNA damage response in osteosarcoma models [43,128]. After irradiation, KDM4B is recruited to DNA damage in a PARP1 dependent manner to remove H3K9me3 at sites of damage [128]. KDM4B activity can influence 53BP1 recruitment to DNA damage sites [43]. After recruitment to double strand breaks, KDM4B is marked by RNF8 and RNF168 and degraded in the proteasome [43]. Combined, these findings suggest that KDM4B is a novel risk factor or biomarker in osteosarcoma.

\subsection{KDM4B in Hematological Tumors}

The role of KDM4B activity in hematological cancers has been explored in acute myeloid leukemia (AML) and multiple myeloma (MM) [123,129]. AML with translocations of the mixed-lineage leukemia 1 (MLL1) gene are aggressive hematopoietic malignancies, developing resistance to chemotherapies [123]. Using KDM4A, KDM4B, and KDM4C triple knockout mice, KDM4 demethylation of H3K9me3 was shown to be required for MLL-AF9 translocated AML pathogenesis in vitro and in vivo [123]. A possible redundant role was identified for KDM4 family proteins in AML and non-transformed bone marrow [123]. When only KDM4C is knocked out in AML mouse models, leukemic cells survive [123]. IL3RA ectopic expression alleviated the need for KDM4 proteins for survival and was shown to be a critical downstream target for KDM4 proteins in AML [123]. These findings suggest that KDM4B and other KDM4 enzymes could be promising drug targets in AML.

Multiple Myeloma is a plasma cell neoplasm characterized by the accumulation of terminally differentiated monoclonal plasma cells in the bone marrow and is one of the most diagnosed hematological cancer types [129]. Evidence suggests epigenetics are involved in the gene expression changes driving MM progression [129]. Triptolide induces apoptosis in AML and was explored for its effects on histone methylation and antitumor effect on MM [129]. Triptolide treatment induced apoptosis, and decreased KDM4B and H3K9me2 expression in MM [129]. These findings are consistent with studies demonstrating that KDM4B may have a protective role in apoptosis, mediating the DNA damage response [129]. These observations suggest high KDM4B expression may drive MM progression, but this needs further exploration. 
In contrast to it role in myeloma progression, KDM4B may play a tumor suppressive role in chronic lymphotic leukemia (CLL). KDM4B expression is decreased in CLL compared to control tissues, particularly in the more aggressive and resistant ZAP-70 positive CLL cells (130). KDM4A is increased in CLL, and KDM4C is unchanged but is lower in ZAP-70 positive cells [130]. This suggests that inhibiting KDM4B in hematological cancers may have conflicting outcomes, depending on the tumors being treated.

\subsection{KDM4B in Gynecological Cancers}

KDM4B has been poorly explored in gynecological cancers. Gynecological cancers, particularly high grade serous ovarian carcinomas, are plagued with late diagnoses and high metastatic tumor burden at the time of surgery [131]. The high tumor load at the time of primary surgery is also a contributing factor to the rapid rate of recurrence and incidence of chemotherapeutic resistance [132]. KDM4B has been shown to promote endometrial cancer progression by regulating androgen receptor, c-Myc, and p27 ${ }^{\mathrm{kip} 1}$ [107]. KDM4B regulates genes associated with seeding of ovarian cancer cells to the peritoneal and omental tissues during metastasis (PDGFB, LOX, LOXL2, and LCN2) [35]. In this case, KDM4B was primarily studied as a contributing factor to high grade serous ovarian carcinoma (HGSOC) via hypoxic regulation of metastatic mechanisms. TP53 is mutated or lost in over $90 \%$ of HGSOC, removing one potential mode of regulation from consideration [133]. Similarly, although many HGSOC tumors express estrogen receptor, neither estrogen nor SERMS significantly influence patient outcomes $[134,135]$. Unfortunately, expression of KDM4B mRNA is not associated with either poor or improved prognosis in HGSOC [133]. This does not mean that KDM4B is not important for mediating tumorigenic mechanisms in ovarian cancer, but it does mean that expression does not correlate with prognosis during conventional platinum-Taxol therapies. More studies are required to determine if the mechanisms regulated by KDM4B in gynecological cancers overlap with pathways targeted by current and emerging chemotherapies.

\subsection{KDM4B in Other Cancers}

KDM4B activity is also linked to liver, lung, and bladder cancer development $[118,119,136]$. KDM4B shows increased expression correlating with tumor grade severity in Hepatocellular carcinoma (HCC) [136]. KDM4B is highly expressed in lung and bladder tissue compared to normal tissues [119]. Knockdown of KDM4B in lung and bladder cancer models showed decreased proliferation and decreased colony formation, through decreased expression of CDK6 [119]. KDM4B has also been shown to regulate the N-Myc pathway in neuroblastoma [137]. KDM4B and N-Myc are highly expressed in neuroblastoma tumors and correlate with poor outcome [137]. Co-IP analysis showed binding between KDM4B and N-Myc [137]. When KDM4B is knocked down, there is decreased proliferation, differentiation and tumor growth in neuroblastoma models [137]. KDM4B expression and activity has also been explored in the progression of uveal melanoma [138]. In addition to aberrant expression of other histone modifiers, KDM4B was found to be down-regulated in uveal melanoma with monosomy 3 [138]. Monosomy 3 is one of the predictive markers of poor prognosis in this cancer type [139]. These findings implicate KDM4B as a general facilitator of tumor progression with diverse roles in mediating progression.

\section{KDM4B as a Therapeutic Target (i.e., a Nail for Every Hammer)?}

When analyzed in isolation, KDM4B regulates a broad suite of pathways that promote whatever pathological condition is the focus of study. This would seem to make it an excellent target for therapeutic development, particularly in the multiple cancers where KDM4B contributes to progression. Given the central importance of epigenetic regulation in tumor progression, inhibitors of KDM4B and many other JmjC-KDMs are being actively developed for clinical application [140-147]. We refer the reader to some comprehensive reviews describing the multiple types of KDM inhibitors currently in development, and the respective mechanisms of action $[10,148]$. Although there has been significant 
progress, the commonality of the reaction mechanisms between the various JmjC-KDM family members frequently results in inhibition of enzymes in other subfamilies [140]. In the case of the KDM4 family, where elevated expression seems to be a hallmark of many cancers, it may not be important to distinguish between KDM4A, KDM4B, KDM4C, and KDM4D. Specifically targeting KDM4B with shRNA increased KDM4D RNA and protein expression in ovarian cancer cells [35]. Targeting all KDM4 enzymes at once would prevent any compensatory expression, yielding maximum clinical efficacy. On the other hand, given the clear importance of KDM4B for basic cellular functions in normal tissues, particularly stem cell maintenance and proliferation, one might predict that inhibiting its activity could result in debilitating side effects comparable to those observed with existing anti-proliferative chemotherapies (e.g., gastrointestinal and renal dysfunction, neutropenia, and anemia).

A more promising avenue for targeting KDM4B may lie in mediating "synthetic lethality." A subset of tumors harbor mutations in isocitrate dehydrogenase 1 and 2 (IDH1/2), resulting in the aberrant conversion of of $\alpha$-ketoglutarate (2-oxoglutarate, 2-OG) to the the R enantiomer of 2-hydroxyglutarate (R-2-HG), an inhibitor of JmjC histone demethylases and TET DNA demethylases [149-152]. In recent studies, R-2HG is 3 times more effective at inhibiting KDM4B than S-2HG in vitro ( $\mathrm{Km}$ of $150 \mu \mathrm{M}$ vs. $450 \mu \mathrm{M}$ ) [153]. IDH mutant cells are more sensitive to PARP inhibitors (PARPis), increasing DNA damage and cell death [154]. Loss of KDM4A and KDM4B increases DNA damage in wild-type IDH backgrounds, while over expression of either reverses the effect of IDH mutation [154]. The Krebs cycle intermediates citrate, succinate and fumarate, can also inhibit JmjC-KDMs and promote defects in homologous recombination that increase sensitivity to PARPis (albeit with much higher $\mathrm{Km}$ than R-2HG) $[153,155]$. Although specifically restricting KDM4B inhibition to a tumor remains challenging, identifying conditions where KDM4B is inhibited by aberrant metabolite accumulation could more effectively direct the application of PARPis and other chemotherapeutics.

The old proverb "For a man with a hammer, everything looks like a nail" refers to the all too human tendency to address a new problem with the tools that we are most familiar. In the case of KDM4B, which is regulated by multiple stimuli, in multiple cell types, in multiple pathological conditions, it would seem to be an ideal "nail" for several therapeutic "hammers." However, the contributions of KDM4B to such a broad spectrum of biological processes suggests that a great deal more research is required to convert its clear biological importance into the development of effective therapeutic strategies.

Funding: P20 GM104936 (A.J.K.); R21 HD094983 (A.J.K.).

Acknowledgments: This work was supported by an Institutional Development Award (IDeA) P20GM104936 (A.J.K.) and R21HD094983 (A.J.K.).

Conflicts of Interest: The authors have no potential conflicts of interest for this manuscript.

\section{References}

1. Black, J.C.; Van Rechem, C.; Whetstine, J.R. Histone lysine methylation dynamics: Establishment, regulation, and biological impact. Mol. Cell 2012, 48, 491-507. [CrossRef] [PubMed]

2. Trewick, S.C.; McLaughlin, P.J.; Allshire, R.C. Methylation: Lost in hydroxylation? EMBO Rep. 2005, 6, 315-320. [CrossRef] [PubMed]

3. Shi, Y.; Lan, F.; Matson, C.; Mulligan, P.; Whetstine, J.R.; Cole, P.A.; Casero, R.A.; Shi, Y. Histone demethylation mediated by the nuclear amine oxidase homolog LSD1. Cell 2004, 119, 941-953. [CrossRef] [PubMed]

4. Tsukada, Y.; Fang, J.; Erdjument-Bromage, H.; Warren, M.E.; Borchers, C.H.; Tempst, P.; Zhang, Y. Histone demethylation by a family of JmjC domain-containing proteins. Nature 2006, 439, 811-816. [CrossRef] [PubMed]

5. Whetstine, J.R.; Nottke, A.; Lan, F.; Huarte, M.; Smolikov, S.; Chen, Z.; Spooner, E.; Li, E.; Zhang, G.; Colaiacovo, M.; et al. Reversal of histone lysine trimethylation by the JMJD2 family of histone demethylases. Cell 2006, 125, 467-481. [CrossRef] 
6. Cloos, P.A.; Christensen, J.; Agger, K.; Maiolica, A.; Rappsilber, J.; Antal, T.; Hansen, K.H.; Helin, K. The putative oncogene GASC1 demethylates tri- and dimethylated lysine 9 on histone H3. Nature 2006, 442, 307-311. [CrossRef] [PubMed]

7. Takeuchi, T.; Yamazaki, Y.; Katoh-Fukui, Y.; Tsuchiya, R.; Kondo, S.; Motoyama, J.; Higashinakagawa, T. Gene trap capture of a novel mouse gene, jumonji, required for neural tube formation. Genes Dev. 1995, 9, 1211-1222. [CrossRef]

8. Klose, R.J.; Kallin, E.M.; Zhang, Y. JmjC-domain-containing proteins and histone demethylation. Nat. Rev. Genet. 2006, 7, 715-727. [CrossRef]

9. Pedersen, M.T.; Helin, K. Histone demethylases in development and disease. Trends Cell Biol. 2010, 20, 662-671. [CrossRef]

10. Hancock, R.L.; Dunne, K.; Walport, L.J.; Flashman, E.; Kawamura, A. Epigenetic regulation by histone demethylases in hypoxia. Epigenomics 2015, 7, 791-811. [CrossRef]

11. Huang, F.; Chandrasekharan, M.B.; Chen, Y.C.; Bhaskara, S.; Hiebert, S.W.; Sun, Z.W. The JmjN domain of Jhd2 is important for its protein stability, and the plant homeodomain (PHD) finger mediates its chromatin association independent of H3K4 methylation. J. Biol. Chem. 2010, 285, 24548-24561. [CrossRef] [PubMed]

12. Quan, Z.; Oliver, S.G.; Zhang, N. JmjN interacts with JmjC to ensure selective proteolysis of Gis1 by the proteasome. Microbiology 2011, 157, 2694-2701. [CrossRef] [PubMed]

13. Pasini, D.; Cloos, P.A.; Walfridsson, J.; Olsson, L.; Bukowski, J.P.; Johansen, J.V.; Bak, M.; Tommerup, N.; Rappsilber, J.; Helin, K. JARID2 regulates binding of the Polycomb repressive complex 2 to target genes in ES cells. Nature 2010, 464, 306-310. [CrossRef] [PubMed]

14. Peng, J.C.; Valouev, A.; Swigut, T.; Zhang, J.; Zhao, Y.; Sidow, A.; Wysocka, J. Jarid2/Jumonji coordinates control of PRC2 enzymatic activity and target gene occupancy in pluripotent cells. Cell 2009, 139, 1290-1302. [CrossRef] [PubMed]

15. Shen, X.; Kim, W.; Fujiwara, Y.; Simon, M.D.; Liu, Y.; Mysliwiec, M.R.; Yuan, G.C.; Lee, Y.; Orkin, S.H. Jumonji modulates polycomb activity and self-renewal versus differentiation of stem cells. Cell 2009, 139, 1303-1314. [CrossRef] [PubMed]

16. Berry, W.L.; Janknecht, R. KDM4/JMJD2 histone demethylases: Epigenetic regulators in cancer cells. Cancer Res. 2013, 73, 2936-2942. [CrossRef] [PubMed]

17. Katoh, M.; Katoh, M. Identification and characterization of JMJD2 family genes in silico. Int. J. Oncol. 2004, 24, 1623-1628. [PubMed]

18. Levin, M.; Stark, M.; Assaraf, Y.G. The JmjN domain as a dimerization interface and a targeted inhibitor of KDM4 demethylase activity. Oncotarget 2018, 9, 16861-16882. [CrossRef]

19. Hillringhaus, L.; Yue, W.W.; Rose, N.R.; Ng, S.S.; Gileadi, C.; Loenarz, C.; Bello, S.H.; Bray, J.E.; Schofield, C.J.; Oppermann, U. Structural and evolutionary basis for the dual substrate selectivity of human KDM4 histone demethylase family. J. Biol. Chem. 2011, 286, 41616-41625. [CrossRef]

20. Fodor, B.D.; Kubicek, S.; Yonezawa, M.; O'Sullivan, R.J.; Sengupta, R.; Perez-Burgos, L.; Opravil, S.; Mechtler, K.; Schotta, G.; Jenuwein, T. Jmjd2b antagonizes H3K9 trimethylation at pericentric heterochromatin in mammalian cells. Genes Dev. 2006, 20, 1557-1562. [CrossRef]

21. Rotili, D.; Mai, A. Targeting Histone Demethylases: A New Avenue for the Fight against Cancer. Genes Cancer 2011, 2, 663-679. [CrossRef]

22. Rose, N.R.; McDonough, M.A.; King, O.N.; Kawamura, A.; Schofield, C.J. Inhibition of 2-oxoglutarate dependent oxygenases. Chem. Soc. Rev. 2011, 40, 4364-4397. [CrossRef]

23. Pedersen, M.T.; Kooistra, S.M.; Radzisheuskaya, A.; Laugesen, A.; Johansen, J.V.; Hayward, D.G.; Nilsson, J.; Agger, K.; Helin, K. Continual removal of H3K9 promoter methylation by Jmjd2 demethylases is vital for ESC self-renewal and early development. EMBO J. 2016, 35, 1550-1564. [CrossRef]

24. Roadmap Epigenomics, C.; Kundaje, A.; Meuleman, W.; Ernst, J.; Bilenky, M.; Yen, A.; Heravi-Moussavi, A.; Kheradpour, P.; Zhang, Z.; Wang, J.; et al. Integrative analysis of 111 reference human epigenomes. Nature 2015, 518, 317-330.

25. Mozzetta, C.; Boyarchuk, E.; Pontis, J.; Ait-Si-Ali, S. Sound of silence: The properties and functions of repressive Lys methyltransferases. Nat. Rev. Mol. Cell Biol. 2015, 16, 499-513. [CrossRef]

26. Mikkelsen, T.S.; Ku, M.; Jaffe, D.B.; Issac, B.; Lieberman, E.; Giannoukos, G.; Alvarez, P.; Brockman, W.; Kim, T.K.; Koche, R.P.; et al. Genome-wide maps of chromatin state in pluripotent and lineage-committed cells. Nature 2007, 448, 553-560. [CrossRef] 
27. Wang, Z.; Zang, C.; Rosenfeld, J.A.; Schones, D.E.; Barski, A.; Cuddapah, S.; Cui, K.; Roh, T.Y.; Peng, W.; Zhang, M.Q.; et al. Combinatorial patterns of histone acetylations and methylations in the human genome. Nat. Genet. 2008, 40, 897-903. [CrossRef]

28. Barski, A.; Cuddapah, S.; Cui, K.; Roh, T.Y.; Schones, D.E.; Wang, Z.; Wei, G.; Chepelev, I.; Zhao, K. High-resolution profiling of histone methylations in the human genome. Cell 2007, 129, 823-837. [CrossRef]

29. Vakoc, C.R.; Sachdeva, M.M.; Wang, H.; Blobel, G.A. Profile of histone lysine methylation across transcribed mammalian chromatin. Mol. Cell. Biol. 2006, 26, 9185-9195. [CrossRef]

30. Vakoc, C.R.; Mandat, S.A.; Olenchock, B.A.; Blobel, G.A. Histone H3 lysine 9 methylation and HP1 $\gamma$ are associated with transcription elongation through mammalian chromatin. Mol. Cell 2005, 19, 381-391. [CrossRef]

31. Yokochi, T.; Poduch, K.; Ryba, T.; Lu, J.; Hiratani, I.; Tachibana, M.; Shinkai, Y.; Gilbert, D.M. G9a selectively represses a class of late-replicating genes at the nuclear periphery. Proc. Natl. Acad. Sci. USA 2009, 106, 19363-19368. [CrossRef]

32. Kind, J.; Pagie, L.; Ortabozkoyun, H.; Boyle, S.; de Vries, S.S.; Janssen, H.; Amendola, M.; Nolen, L.D.; Bickmore, W.A.; van Steensel, B. Single-cell dynamics of genome-nuclear lamina interactions. Cell 2013, 153, 178-192. [CrossRef]

33. Wu, R.; Terry, A.V.; Singh, P.B.; Gilbert, D.M. Differential subnuclear localization and replication timing of histone H3 lysine 9 methylation states. Mol. Biol. Cell 2005, 16, 2872-2881. [CrossRef]

34. Das, P.P.; Shao, Z.; Beyaz, S.; Apostolou, E.; Pinello, L.; De Los Angeles, A.; O’Brien, K.; Atsma, J.M.; Fujiwara, Y.; Nguyen, M.; et al. Distinct and combinatorial functions of Jmjd2b/Kdm4b and Jmjd2c/Kdm4c in mouse embryonic stem cell identity. Mol. Cell 2014, 53, 32-48. [CrossRef]

35. Wilson, C.; Qiu, L.; Hong, Y.; Karnik, T.; Tadros, G.; Mau, B.; Ma, T.; Mu, Y.; New, J.; Louie, R.J.; et al. The histone demethylase KDM4B regulates peritoneal seeding of ovarian cancer. Oncogene 2017, 36, 2565-2576. [CrossRef]

36. Yang, J.; Jubb, A.M.; Pike, L.; Buffa, F.M.; Turley, H.; Baban, D.; Leek, R.; Gatter, K.C.; Ragoussis, J.; Harris, A.L. The histone demethylase JMJD2B is regulated by estrogen receptor $\alpha$ and hypoxia, and is a key mediator of estrogen induced growth. Cancer Res. 2010, 70, 6456-6466. [CrossRef]

37. Loh, Y.H.; Zhang, W.; Chen, X.; George, J.; Ng, H.H. Jmjd1a and Jmjd2c histone H3 Lys 9 demethylases regulate self-renewal in embryonic stem cells. Genes Dev. 2007, 21, 2545-2557. [CrossRef]

38. Castellini, L.; Moon, E.J.; Razorenova, O.V.; Krieg, A.J.; von Eyben, R.; Giaccia, A.J. KDM4B/JMJD2B is a p53 target gene that modulates the amplitude of p53 response after DNA damage. Nucleic Acids Res. 2017, 45, 3674-3692. [CrossRef]

39. Ponnaluri, V.K.; Vavilala, D.T.; Putty, S.; Gutheil, W.G.; Mukherji, M. Identification of non-histone substrates for JMJD2A-C histone demethylases. Biochem. Biophys. Res. Commun. 2009, 390, 280-284. [CrossRef]

40. Yang, J.; Harris, A.L.; Davidoff, A.M. Hypoxia and Hormone-Mediated Pathways Converge at the Histone Demethylase KDM4B in Cancer. Int. J. Mol. Sci. 2018, 19, 240. [CrossRef]

41. Lee, J.; Thompson, J.R.; Botuyan, M.V.; Mer, G. Distinct binding modes specify the recognition of methylated histones H3K4 and H4K20 by JMJD2A-tudor. Nat. Struct. Mol. Biol. 2008, 15, 109-111. [CrossRef]

42. Su, Z.; Wang, F.; Lee, J.H.; Stephens, K.E.; Papazyan, R.; Voronina, E.; Krautkramer, K.A.; Raman, A.; Thorpe, J.J.; Boersma, M.D.; et al. Reader domain specificity and lysine demethylase-4 family function. Nat. Commun. 2016, 7, 13387. [CrossRef]

43. Mallette, F.A.; Mattiroli, F.; Cui, G.; Young, L.C.; Hendzel, M.J.; Mer, G.; Sixma, T.K.; Richard, S. RNF8- and RNF168-dependent degradation of KDM4A/JMJD2A triggers 53BP1 recruitment to DNA damage sites. EMBO J. 2012, 31, 1865-1878. [CrossRef]

44. Beyer, S.; Kristensen, M.M.; Jensen, K.S.; Johansen, J.V.; Staller, P. The histone demethylases JMJD1A and JMJD2B are transcriptional targets of hypoxia-inducible factor HIF. J. Biol. Chem. 2008, 283, 36542-36552. [CrossRef]

45. Pollard, P.J.; Loenarz, C.; Mole, D.R.; McDonough, M.A.; Gleadle, J.M.; Schofield, C.J.; Ratcliffe, P.J. Regulation of Jumonji-domain-containing histone demethylases by hypoxia-inducible factor (HIF)-1 $\alpha$. Biochem. J. 2008, 416, 387-394. [CrossRef]

46. Xia, X.; Lemieux, M.E.; Li, W.; Carroll, J.S.; Brown, M.; Liu, X.S.; Kung, A.L. Integrative analysis of HIF binding and transactivation reveals its role in maintaining histone methylation homeostasis. Proc. Natl. Acad. Sci. USA 2009, 106, 4260-4265. [CrossRef] 
47. Ramachandran, S.; Ient, J.; Gottgens, E.L.; Krieg, A.J.; Hammond, E.M. Epigenetic Therapy for Solid Tumors: Highlighting the Impact of Tumor Hypoxia. Genes 2015, 6, 935-956. [CrossRef]

48. Hammond, E.M.; Giaccia, A.J. Hypoxia-inducible factor-1 and p53: Friends, acquaintances, or strangers? Clin. Cancer Res. 2006, 12, 5007-5009. [CrossRef]

49. Thomlinson, R.H.; Gray, L.H. The histological structure of some human lung cancers and the possible implications for radiotherapy. Br. J. Cancer 1955, 9, 539-549. [CrossRef]

50. Trotter, M.J.; Chaplin, D.J.; Durand, R.E.; Olive, P.L. The use of fluorescent probes to identify regions of transient perfusion in murine tumors. Int. J. Radiat. Oncol. Biol. Phys. 1989, 16, 931-934. [CrossRef]

51. Brown, J.M.; Giaccia, A.J. The unique physiology of solid tumors: Opportunities (and problems) for cancer therapy. Cancer Res. 1998, 58, 1408-1416.

52. Chan, D.A.; Giaccia, A.J. Hypoxia, gene expression, and metastasis. Cancer Metastasis Rev. 2007, 26, 333-339. [CrossRef]

53. Rankin, E.B.; Giaccia, A.J. Hypoxic control of metastasis. Science 2016, 352, 175-180. [CrossRef]

54. Mole, D.R.; Blancher, C.; Copley, R.R.; Pollard, P.J.; Gleadle, J.M.; Ragoussis, J.; Ratcliffe, P.J. Genome-wide association of hypoxia-inducible factor (HIF)- $1 \alpha$ and HIF-2 $\alpha$ DNA binding with expression profiling of hypoxia-inducible transcripts. J. Biol. Chem. 2009, 284, 16767-16775. [CrossRef]

55. Raval, R.R.; Lau, K.W.; Tran, M.G.; Sowter, H.M.; Mandriota, S.J.; Li, J.L.; Pugh, C.W.; Maxwell, P.H.; Harris, A.L.; Ratcliffe, P.J. Contrasting properties of hypoxia-inducible factor 1 (HIF-1) and HIF-2 in von Hippel-Lindau-associated renal cell carcinoma. Mol. Cell. Biol. 2005, 25, 5675-5686. [CrossRef]

56. Manalo, D.J.; Rowan, A.; Lavoie, T.; Natarajan, L.; Kelly, B.D.; Ye, S.Q.; Garcia, J.G.; Semenza, G.L. Transcriptional regulation of vascular endothelial cell responses to hypoxia by HIF-1. Blood 2005, 105, 659-669. [CrossRef]

57. Epstein, A.C.; Gleadle, J.M.; McNeill, L.A.; Hewitson, K.S.; O’Rourke, J.; Mole, D.R.; Mukherji, M.; Metzen, E.; Wilson, M.I.; Dhanda, A.; et al. C. elegans EGL-9 and mammalian homologs define a family of dioxygenases that regulate HIF by prolyl hydroxylation. Cell 2001, 107, 43-54. [CrossRef]

58. Ivan, M.; Kaelin, W.G., Jr. The EGLN-HIF O 2 -Sensing System: Multiple Inputs and Feedbacks. Mol. Cell 2017, 66, 772-779. [CrossRef]

59. Ivan, M.; Haberberger, T.; Gervasi, D.C.; Michelson, K.S.; Gunzler, V.; Kondo, K.; Yang, H.; Sorokina, I.; Conaway, R.C.; Conaway, J.W.; et al. Biochemical purification and pharmacological inhibition of a mammalian prolyl hydroxylase acting on hypoxia-inducible factor. Proc. Natl. Acad. Sci. USA 2002, 99, 13459-13464. [CrossRef]

60. Jaakkola, P.; Mole, D.R.; Tian, Y.M.; Wilson, M.I.; Gielbert, J.; Gaskell, S.J.; von Kriegsheim, A.; Hebestreit, H.F.; Mukherji, M.; Schofield, C.J.; et al. Targeting of HIF- $\alpha$ to the von Hippel-Lindau ubiquitylation complex by $\mathrm{O}_{2}$-regulated prolyl hydroxylation. Science 2001, 292, 468-472. [CrossRef]

61. Masson, N.; Willam, C.; Maxwell, P.H.; Pugh, C.W.; Ratcliffe, P.J. Independent function of two destruction domains in hypoxia-inducible factor- $\alpha$ chains activated by prolyl hydroxylation. EMBO J. 2001, 20, 5197-5206. [CrossRef]

62. Ivan, M.; Kondo, K.; Yang, H.; Kim, W.; Valiando, J.; Ohh, M.; Salic, A.; Asara, J.M.; Lane, W.S.; Kaelin, W.G., Jr. $\mathrm{HIF} \alpha$ targeted for VHL-mediated destruction by proline hydroxylation: Implications for $\mathrm{O}_{2}$ sensing. Science 2001, 292, 464-468. [CrossRef]

63. Maxwell, P.H.; Wiesener, M.S.; Chang, G.W.; Clifford, S.C.; Vaux, E.C.; Cockman, M.E.; Wykoff, C.C.; Pugh, C.W.; Maher, E.R.; Ratcliffe, P.J. The tumour suppressor protein VHL targets hypoxia-inducible factors for oxygen-dependent proteolysis. Nature 1999, 399, 271-275. [CrossRef]

64. Min, J.H.; Yang, H.; Ivan, M.; Gertler, F.; Kaelin, W.G., Jr.; Pavletich, N.P. Structure of an HIF-1 $\alpha-p V H L$ complex: Hydroxyproline recognition in signaling. Science 2002, 296, 1886-1889. [CrossRef]

65. Wang, G.L.; Jiang, B.H.; Rue, E.A.; Semenza, G.L. Hypoxia-inducible factor 1 is a basic-helix-loop-helix-PAS heterodimer regulated by cellular $\mathrm{O} 2$ tension. Proc. Natl. Acad. Sci. USA 1995, 92, 5510-5514. [CrossRef]

66. Wang, G.L.; Semenza, G.L. Purification and characterization of hypoxia-inducible factor 1. J. Biol. Chem. 1995, 270, 1230-1237. [CrossRef]

67. Krieg, A.J.; Rankin, E.B.; Chan, D.; Razorenova, O.; Fernandez, S.; Giaccia, A.J. Regulation of the histone demethylase JMJD1A by hypoxia-inducible factor $1 \alpha$ enhances hypoxic gene expression and tumor growth. Mol. Cell. Biol. 2010, 30, 344-353. [CrossRef] 
68. Hancock, R.L.; Masson, N.; Dunne, K.; Flashman, E.; Kawamura, A. The Activity of JmjC Histone Lysine Demethylase KDM4A is Highly Sensitive to Oxygen Concentrations. ACS Chem. Biol. 2017, 12, 1011-1019. [CrossRef]

69. Tarhonskaya, H.; Hardy, A.P.; Howe, E.A.; Loik, N.D.; Kramer, H.B.; McCullagh, J.S.; Schofield, C.J.; Flashman, E. Kinetic Investigations of the Role of Factor Inhibiting Hypoxia-inducible Factor (FIH) as an Oxygen Sensor. J. Biol. Chem. 2015, 290, 19726-19742. [CrossRef]

70. Koivunen, P.; Hirsila, M.; Gunzler, V.; Kivirikko, K.I.; Myllyharju, J. Catalytic properties of the asparaginyl hydroxylase (FIH) in the oxygen sensing pathway are distinct from those of its prolyl 4-hydroxylases. J. Biol. Chem. 2004, 279, 9899-9904. [CrossRef]

71. Kang, C.; Saso, K.; Ota, K.; Kawazu, M.; Ueda, T.; Okada, H. JMJD2B/KDM4B inactivation in adipose tissues accelerates obesity and systemic metabolic abnormalities. Genes Cells 2018, 23, 767-777. [CrossRef]

72. Cheng, Y.; Yuan, Q.; Vergnes, L.; Rong, X.; Youn, J.Y.; Li, J.; Yu, Y.; Liu, W.; Cai, H.; Lin, J.D.; et al. KDM4B protects against obesity and metabolic dysfunction. Proc. Natl. Acad. Sci. USA 2018, 115, E5566-E5575. [CrossRef]

73. Shi, L.; Sun, L.; Li, Q.; Liang, J.; Yu, W.; Yi, X.; Yang, X.; Li, Y.; Han, X.; Zhang, Y.; et al. Histone demethylase JMJD2B coordinates H3K4/H3K9 methylation and promotes hormonally responsive breast carcinogenesis. Proc. Natl. Acad. Sci. USA 2011, 108, 7541-7546. [CrossRef]

74. Kawazu, M.; Saso, K.; Tong, K.I.; McQuire, T.; Goto, K.; Son, D.O.; Wakeham, A.; Miyagishi, M.; Mak, T.W.; Okada, H. Histone demethylase JMJD2B functions as a co-factor of estrogen receptor in breast cancer proliferation and mammary gland development. PLOS ONE 2011, 6, e17830. [CrossRef]

75. Gaughan, L.; Stockley, J.; Coffey, K.; O’Neill, D.; Jones, D.L.; Wade, M.; Wright, J.; Moore, M.; Tse, S.; Rogerson, L.; et al. KDM4B is a master regulator of the estrogen receptor signalling cascade. Nucleic Acids Res. 2013, 41, 6892-6904. [CrossRef]

76. West, D.C.; Pan, D.; Tonsing-Carter, E.Y.; Hernandez, K.M.; Pierce, C.F.; Styke, S.C.; Bowie, K.R.; Garcia, T.I.; Kocherginsky, M.; Conzen, S.D. GR and ER Coactivation Alters the Expression of Differentiation Genes and Associates with Improved ER+ Breast Cancer Outcome. Mol. Cancer Res. 2016, 14, 707-719. [CrossRef]

77. Coffey, K.; Rogerson, L.; Ryan-Munden, C.; Alkharaif, D.; Stockley, J.; Heer, R.; Sahadevan, K.; O’Neill, D.; Jones, D.; Darby, S.; et al. The lysine demethylase, KDM4B, is a key molecule in androgen receptor signalling and turnover. Nucleic Acids Res. 2013, 41, 4433-4446. [CrossRef]

78. Chu, C.H.; Wang, L.Y.; Hsu, K.C.; Chen, C.C.; Cheng, H.H.; Wang, S.M.; Wu, C.M.; Chen, T.J.; Li, L.T.; Liu, R.; et al. KDM4B as a target for prostate cancer: Structural analysis and selective inhibition by a novel inhibitor. J. Med. Chem. 2014, 57, 5975-5985. [CrossRef]

79. Heinlein, C.A.; Chang, C. Androgen receptor in prostate cancer. Endocr. Rev. 2004, 25, 276-308. [CrossRef]

80. Li, X.; Dong, S. Histone demethylase JMJD2B and JMJD2C induce fibroblast growth factor 2: Mediated tumorigenesis of osteosarcoma. Med. Oncol. 2015, 32, 53. [CrossRef]

81. Zheng, H.; Chen, L.; Pledger, W.J.; Fang, J.; Chen, J. p53 promotes repair of heterochromatin DNA by regulating JMJD2b and SUV39H1 expression. Oncogene 2014, 33, 734-744. [CrossRef]

82. Kim, J.G.; Yi, J.M.; Park, S.J.; Kim, J.S.; Son, T.G.; Yang, K.; Yoo, M.A.; Heo, K. Histone demethylase JMJD2B-mediated cell proliferation regulated by hypoxia and radiation in gastric cancer cell. Biochim. Biophys. Acta 2012, 1819, 1200-1207. [CrossRef]

83. Zimmermann, M.; de Lange, T. 53BP1: Pro choice in DNA repair. Trends Cell Biol. 2014, 24, $108-117$. [CrossRef]

84. Mishra, S.; Van Rechem, C.; Pal, S.; Clarke, T.L.; Chakraborty, D.; Mahan, S.D.; Black, J.C.; Murphy, S.E.; Lawrence, M.S.; Daniels, D.L.; et al. Cross-talk between Lysine-Modifying Enzymes Controls Site-Specific DNA Amplifications. Cell 2018, 175, 1716. [CrossRef]

85. Black, J.C.; Atabakhsh, E.; Kim, J.; Biette, K.M.; Van Rechem, C.; Ladd, B.; Burrowes, P.D.; Donado, C.; Mattoo, H.; Kleinstiver, B.P.; et al. Hypoxia drives transient site-specific copy gain and drug-resistant gene expression. Genes Dev. 2015, 29, 1018-1031. [CrossRef]

86. Black, J.C.; Manning, A.L.; Van Rechem, C.; Kim, J.; Ladd, B.; Cho, J.; Pineda, C.M.; Murphy, N.; Daniels, D.L.; Montagna, C.; et al. KDM4A lysine demethylase induces site-specific copy gain and rereplication of regions amplified in tumors. Cell 2013, 154, 541-555. [CrossRef] 
87. Xiang, Y.; Yan, K.; Zheng, Q.; Ke, H.; Cheng, J.; Xiong, W.; Shi, X.; Wei, L.; Zhao, M.; Yang, F.; et al. Histone demethylase KDM4B promotes DNA damage by activating long interspersed nuclear element-1. Cancer Res. 2018. [CrossRef]

88. $\quad$ Deng, W.W.; Hu, Q.; Liu, Z.R.; Chen, Q.H.; Wang, W.X.; Zhang, H.G.; Zhang, Q.; Huang, Y.L.; Zhang, X.K. KDM4B promotes DNA damage response via STAT3 signaling and is a target of CREB in colorectal cancer cells. Mol. Cell. Biochem. 2018, 449, 81-90. [CrossRef]

89. Lee, H.L.; Yu, B.; Deng, P.; Wang, C.Y.; Hong, C. Transforming Growth Factor-beta-Induced KDM4B Promotes Chondrogenic Differentiation of Human Mesenchymal Stem Cells. Stem Cells 2016, 34, 711-719. [CrossRef]

90. Dambacher, S.; Hahn, M.; Schotta, G. Epigenetic regulation of development by histone lysine methylation. Heredity 2010, 105, 24-37. [CrossRef]

91. Katoh, Y.; Katoh, M. Comparative integromics on JMJD2A, JMJD2B and JMJD2C: Preferential expression of JMJD2C in undifferentiated ES cells. Int. J. Mol. Med. 2007, 20, 269-273. [CrossRef]

92. Volarevic, V.; Bojic, S.; Nurkovic, J.; Volarevic, A.; Ljujic, B.; Arsenijevic, N.; Lako, M.; Stojkovic, M. Stem cells as new agents for the treatment of infertility: Current and future perspectives and challenges. Biomed. Res. Int. 2014, 2014, 507234. [CrossRef]

93. Antony, J.; Oback, F.; Chamley, L.W.; Oback, B.; Laible, G. Transient JMJD2B-mediated reduction of H3K9me3 levels improves reprogramming of embryonic stem cells into cloned embryos. Mol. Cell. Biol. 2013, 33, 974-983. [CrossRef]

94. Liu, Z.; Cai, Y.; Wang, Y.; Nie, Y.; Zhang, C.; Xu, Y.; Zhang, X.; Lu, Y.; Wang, Z.; Poo, M.; et al. Cloning of Macaque Monkeys by Somatic Cell Nuclear Transfer. Cell 2018, 174, 245. [CrossRef]

95. Iwamori, N.; Zhao, M.; Meistrich, M.L.; Matzuk, M.M. The testis-enriched histone demethylase, KDM4D, regulates methylation of histone $\mathrm{H} 3$ lysine 9 during spermatogenesis in the mouse but is dispensable for fertility. Biol. Reprod. 2011, 84, 1225-1234. [CrossRef]

96. Ye, L.; Fan, Z.; Yu, B.; Chang, J.; Al Hezaimi, K.; Zhou, X.; Park, N.H.; Wang, C.Y. Histone demethylases KDM4B and KDM6B promotes osteogenic differentiation of human MSCs. Cell Stem Cell 2012, 11, 50-61. [CrossRef]

97. Qu, B.; Liu, O.; Fang, X.; Zhang, H.; Wang, Y.; Quan, H.; Zhang, J.; Zhou, J.; Zuo, J.; Tang, J.; et al. Distal-less homeobox 2 promotes the osteogenic differentiation potential of stem cells from apical papilla. Cell Tissue Res. 2014, 357, 133-143. [CrossRef]

98. Yang, H.; Fan, J.; Cao, Y.; Gao, R.; Fan, Z. Distal-less homeobox 5 promotes the osteo-/dentinogenic differentiation potential of stem cells from apical papilla by activating histone demethylase KDM4B through a positive feedback mechanism. Exp. Cell. Res. 2019, 374, 221-230. [CrossRef]

99. Guo, L.; Li, X.; Huang, J.X.; Huang, H.Y.; Zhang, Y.Y.; Qian, S.W.; Zhu, H.; Zhang, Y.D.; Liu, Y.; Liu, Y.; et al. Histone demethylase $\mathrm{Kdm} 4 \mathrm{~b}$ functions as a co-factor of $\mathrm{C} / \mathrm{EBPb}$ ta to promote mitotic clonal expansion during differentiation of 3T3-L1 preadipocytes. Cell Death Differ. 2012, 19, 1917-1927. [CrossRef]

100. Tang, Q.Q.; Otto, T.C.; Lane, M.D. Mitotic clonal expansion: A synchronous process required for adipogenesis. Proc. Natl. Acad. Sci. USA 2003, 100, 44-49. [CrossRef]

101. Fujiwara, K.; Fujita, Y.; Kasai, A.; Onaka, Y.; Hashimoto, H.; Okada, H.; Yamashita, T. Deletion of JMJD2B in neurons leads to defective spine maturation, hyperactive behavior and memory deficits in mouse. Transl. Psychiatry 2016, 6, e766. [CrossRef]

102. Uribe, R.A.; Buzzi, A.L.; Bronner, M.E.; Strobl-Mazzulla, P.H. Histone demethylase KDM4B regulates otic vesicle invagination via epigenetic control of Dlx3 expression. J. Cell Biol. 2015, 211, 815-827. [CrossRef]

103. Yoshioka, H.; McCarrey, J.R.; Yamazaki, Y. Dynamic nuclear organization of constitutive heterochromatin during fetal male germ cell development in mice. Biol. Reprod. 2009, 80, 804-812. [CrossRef]

104. Krieg, A.J.; Mullinax, S.R.; Grimstad, F.; Marquis, K.; Constance, E.; Hong, Y.; Krieg, S.A.; Roby, K.F. Histone demethylase KDM4A and KDM4B expression in granulosa cells from women undergoing in vitro fertilization. J. Assist. Reprod. Genet. 2018, 35, 993-1003. [CrossRef]

105. Speroff, L.; Fritz, M.A. Clinical Gynaecologic Endocrinology and Infertility, 7th ed.; Lippincott Williams and Wilkins: Philadelphia, PA, USA, 2005.

106. Krieg, S.A.; Fan, X.; Hong, Y.; Sang, Q.X.; Giaccia, A.; Westphal, L.M.; Lathi, R.B.; Krieg, A.J.; Nayak, N.R. Global alteration in gene expression profiles of deciduas from women with idiopathic recurrent pregnancy loss. Mol. Hum. Reprod. 2012, 18, 442-450. [CrossRef] 
107. Qiu, M.T.; Fan, Q.; Zhu, Z.; Kwan, S.Y.; Chen, L.; Chen, J.H.; Ying, Z.L.; Zhou, Y.; Gu, W.; Wang, L.H.; et al. KDM4B and KDM4A promote endometrial cancer progression by regulating androgen receptor, c-myc, and p27kip1. Oncotarget 2015, 6, 31702-31720. [CrossRef]

108. Tsurumi, A.; Dutta, P.; Shang, R.; Yan, S.J.; Li, W.X. Drosophila Kdm4 demethylases in histone H3 lysine 9 demethylation and ecdysteroid signaling. Sci. Rep. 2013, 3, 2894. [CrossRef]

109. Palomera-Sanchez, Z.; Bucio-Mendez, A.; Valadez-Graham, V.; Reynaud, E.; Zurita, M. Drosophila p53 is required to increase the levels of the AKDM4B demethylase after UV-induced DNA damage to demethylate histone H3 lysine 9. J. Biol. Chem. 2010, 285, 31370-31379. [CrossRef]

110. Xu, W.; Yang, H.; Liu, Y.; Yang, Y.; Wang, P.; Kim, S.H.; Ito, S.; Yang, C.; Wang, P.; Xiao, M.T.; et al. Oncometabolite 2-hydroxyglutarate is a competitive inhibitor of $\alpha$-ketoglutarate-dependent dioxygenases. Cancer Cell 2011, 19, 17-30. [CrossRef]

111. Varier, R.A.; Timmers, H.T. Histone lysine methylation and demethylation pathways in cancer. Biochim. Biophys. Acta 2011, 1815, 75-89. [CrossRef]

112. Hoffmann, I.; Roatsch, M.; Schmitt, M.L.; Carlino, L.; Pippel, M.; Sippl, W.; Jung, M. The role of histone demethylases in cancer therapy. Mol. Oncol. 2012, 6, 683-703. [CrossRef]

113. Thinnes, C.C.; England, K.S.; Kawamura, A.; Chowdhury, R.; Schofield, C.J.; Hopkinson, R.J. Targeting histone lysine demethylases-Progress, challenges, and the future. Biochim. Biophys. Acta 2014, 1839, 1416-1432. [CrossRef]

114. Chizuka, A.; Suda, M.; Shibata, T.; Kusumi, E.; Hori, A.; Hamaki, T.; Kodama, Y.; Horigome, K.; Kishi, Y.; Kobayashi, K.; et al. Difference between hematological malignancy and solid tumor research articles published in four major medical journals. Leukemia 2006, 20, 1655-1657. [CrossRef]

115. Hui, Z.; Yiling, C.; Wenting, Y.; XuQun, H.; ChuanYi, Z.; Hui, L. miR-491-5p functions as a tumor suppressor by targeting JMJD2B in ER $\alpha$-positive breast cancer. FEBS Lett. 2015, 589, 812-821. [CrossRef]

116. Johmura, Y.; Maeda, I.; Suzuki, N.; Wu, W.; Goda, A.; Morita, M.; Yamaguchi, K.; Yamamoto, M.; Nagasawa, S.; Kojima, Y.; et al. Fbxo22-mediated KDM4B degradation determines selective estrogen receptor modulator activity in breast cancer. J. Clin. Investig. 2018, 128, 5603-5619. [CrossRef]

117. Wang, W.; Oguz, G.; Lee, P.L.; Bao, Y.; Wang, P.; Terp, M.G.; Ditzel, H.J.; Yu, Q. KDM4B-regulated unfolded protein response as a therapeutic vulnerability in PTEN-deficient breast cancer. J. Exp. Med. 2018, 215, 2833-2849. [CrossRef]

118. Hwang, S.Y.; Heo, K.; Kim, J.S.; Im, J.W.; Lee, S.M.; Cho, M.; Kang, D.H.; Heo, J.; Lee, J.W.; Choi, C.W.; et al. Emodin attenuates radioresistance induced by hypoxia in HepG2 cells via the enhancement of PARP1 cleavage and inhibition of JMJD2B. Oncol. Rep. 2015, 33, 1691-1698. [CrossRef]

119. Toyokawa, G.; Cho, H.S.; Iwai, Y.; Yoshimatsu, M.; Takawa, M.; Hayami, S.; Maejima, K.; Shimizu, N.; Tanaka, H.; Tsunoda, T.; et al. The histone demethylase JMJD2B plays an essential role in human carcinogenesis through positive regulation of cyclin-dependent kinase 6. Cancer Prev. Res. 2011, 4, 2051-2061. [CrossRef]

120. Berry, W.L.; Kim, T.D.; Janknecht, R. Stimulation of beta-catenin and colon cancer cell growth by the KDM4B histone demethylase. Int. J. Oncol. 2014, 44, 1341-1348. [CrossRef]

121. Han, F.; Ren, J.; Zhang, J.; Sun, Y.; Ma, F.; Liu, Z.; Yu, H.; Jia, J.; Li, W. JMJD2B is required for Helicobacter pylori-induced gastric carcinogenesis via regulating COX-2 expression. Oncotarget 2016. [CrossRef]

122. Li, W.; Zhao, L.; Zang, W.; Liu, Z.; Chen, L.; Liu, T.; Xu, D.; Jia, J. Histone demethylase JMJD2B is required for tumor cell proliferation and survival and is overexpressed in gastric cancer. Biochem. Biophys. Res. Commun. 2011, 416, 372-378. [CrossRef]

123. Agger, K.; Miyagi, S.; Pedersen, M.T.; Kooistra, S.M.; Johansen, J.V.; Helin, K. Jmjd2/Kdm4 demethylases are required for expression of Il3ra and survival of acute myeloid leukemia cells. Genes Dev. 2016, 30, 1278-1288. [CrossRef]

124. Zhao, L.; Li, W.; Zang, W.; Liu, Z.; Xu, X.; Yu, H.; Yang, Q.; Jia, J. JMJD2B promotes epithelial-mesenchymal transition by cooperating with beta-catenin and enhances gastric cancer metastasis. Clin. Cancer Res. 2013, 19, 6419-6429. [CrossRef]

125. Jing, J.C.; Feng, Z.; Chen, Z.H.; Ji, B.N.; Hong, J.; Tang, N.; Yu, J.L.; Wang, S.Y. KDM4B promotes gastric cancer metastasis by regulating miR-125b-mediated activation of Wnt signaling. J. Cell. Biochem. 2018. [CrossRef] 
126. Abarrategi, A.; Tornin, J.; Martinez-Cruzado, L.; Hamilton, A.; Martinez-Campos, E.; Rodrigo, J.P.; Gonzalez, M.V.; Baldini, N.; Garcia-Castro, J.; Rodriguez, R. Osteosarcoma: Cells-of-Origin, Cancer Stem Cells, and Targeted Therapies. Stem Cells Int. 2016, 2016, 3631764. [CrossRef]

127. Ipenberg, I.; Guttmann-Raviv, N.; Khoury, H.P.; Kupershmit, I.; Ayoub, N. Heat shock protein 90 (Hsp90) selectively regulates the stability of KDM4B/JMJD2B histone demethylase. J. Biol. Chem. 2013, 288, 14681-14687. [CrossRef]

128. Young, L.C.; McDonald, D.W.; Hendzel, M.J. Kdm4b histone demethylase is a DNA damage response protein and confers a survival advantage following $\gamma$-irradiation. J. Biol. Chem. 2013, 288, 21376-21388. [CrossRef]

129. Wen, L.; Chen, Y.; Zeng, L.L.; Zhao, F.; Li, R.; Liu, Y.; Zhang, C. Triptolide induces cell-cycle arrest and apoptosis of human multiple myeloma cells in vitro via altering expression of histone demethylase LSD1 and JMJD2B. Acta Pharmacol. Sin. 2012, 33, 109-119. [CrossRef]

130. Filiu-Braga, L.D.C.; Serejo, T.R.T.; Lucena-Araujo, A.R.; Neves, F.A.R.; de Carvalho, J.L.; Rego, E.M.; Saldanha-Araujo, F. Unraveling KDM4 histone demethylase expression and its association with adverse cytogenetic findings in chronic lymphocytic leukemia. Med. Oncol. 2018, 36, 3. [CrossRef]

131. Cho, K.R.; Shih Ie, M. Ovarian cancer. Annu. Rev. Pathol. 2009, 4, 287-313. [CrossRef]

132. Armstrong, D.K. Relapsed ovarian cancer: Challenges and management strategies for a chronic disease. Oncologist 2002, 7 (Suppl. 5), 20-28. [CrossRef]

133. Cancer Genome Atlas Research, N. Integrated genomic analyses of ovarian carcinoma. Nature 2011, 474, 609-615.

134. Lindemann, K.; Gibbs, E.; Avall-Lundqvist, E.; dePont Christensen, R.; Woie, K.; Kalling, M.; Auranen, A.; Grenman, S.; Hoegberg, T.; Rosenberg, P.; et al. Chemotherapy vs tamoxifen in platinum-resistant ovarian cancer: A phase III, randomised, multicentre trial (Ovaresist). Br. J. Cancer 2017, 116, 455-463. [CrossRef]

135. George, A.; McLachlan, J.; Tunariu, N.; Della Pepa, C.; Migali, C.; Gore, M.; Kaye, S.; Banerjee, S. The role of hormonal therapy in patients with relapsed high-grade ovarian carcinoma: A retrospective series of tamoxifen and letrozole. BMC Cancer 2017, 17, 456. [CrossRef]

136. Lu, J.W.; Ho, Y.J.; Lin, L.I.; Huang, Y.C.; Yeh, K.T.; Lin, Y.H.; Lin, Y.M.; Tzeng, T.Y. JMJD2B as a potential diagnostic immunohistochemical marker for hepatocellular carcinoma: A tissue microarray-based study. Acta Histochem. 2015, 117, 14-19. [CrossRef]

137. Yang, J.; AlTahan, A.M.; Hu, D.; Wang, Y.; Cheng, P.H.; Morton, C.L.; Qu, C.; Nathwani, A.C.; Shohet, J.M.; Fotsis, T.; et al. The role of histone demethylase KDM4B in Myc signaling in neuroblastoma. J. Natl. Cancer Inst. 2015, 107, djv080. [CrossRef]

138. Herlihy, N.; Dogrusoz, M.; van Essen, T.H.; Harbour, J.W.; van der Velden, P.A.; van Eggermond, M.C.; Haasnoot, G.W.; van den Elsen, P.J.; Jager, M.J. Skewed expression of the genes encoding epigenetic modifiers in high-risk uveal melanoma. Investig. Ophthalmol. Vis. Sci. 2015, 56, 1447-1458. [CrossRef]

139. Sisley, K.; Cottam, D.W.; Rennie, I.G.; Parsons, M.A.; Potter, A.M.; Potter, C.W.; Rees, R.C. Non-random abnormalities of chromosomes 3, 6, and 8 associated with posterior uveal melanoma. Genes Chromos. Cancer 1992, 5, 197-200. [CrossRef]

140. Hatch, S.B.; Yapp, C.; Montenegro, R.C.; Savitsky, P.; Gamble, V.; Tumber, A.; Ruda, G.F.; Bavetsias, V.; Fedorov, O.; Atrash, B.; et al. Assessing histone demethylase inhibitors in cells: Lessons learned. Epigenet. Chromat. 2017, 10, 9. [CrossRef]

141. Kruidenier, L.; Chung, C.W.; Cheng, Z.; Liddle, J.; Che, K.; Joberty, G.; Bantscheff, M.; Bountra, C.; Bridges, A.; Diallo, H.; et al. A selective jumonji H3K27 demethylase inhibitor modulates the proinflammatory macrophage response. Nature 2012, 488, 404-408. [CrossRef]

142. Rai, G.; Kawamura, A.; Tumber, A.; Liang, Y.; Vogel, J.L.; Arbuckle, J.H.; Rose, N.R.; Dexheimer, T.S.; Foley, T.L.; King, O.N.; et al. Discovery of ML324, a JMJD2 demethylase inhibitor with demonstrated antiviral activity. In Probe Reports from the NIH Molecular Libraries Program; National Center for Biotechnology Information: Bethesda, MD, USA, 2010.

143. Rose, N.R.; Woon, E.C.; Kingham, G.L.; King, O.N.; Mecinovic, J.; Clifton, I.J.; Ng, S.S.; Talib-Hardy, J.; Oppermann, U.; McDonough, M.A.; et al. Selective inhibitors of the JMJD2 histone demethylases: Combined nondenaturing mass spectrometric screening and crystallographic approaches. J. Med. Chem. 2010, 53, 1810-1818. [CrossRef] 
144. Tumber, A.; Nuzzi, A.; Hookway, E.S.; Hatch, S.B.; Velupillai, S.; Johansson, C.; Kawamura, A.; Savitsky, P.; Yapp, C.; Szykowska, A.; et al. Potent and Selective KDM5 Inhibitor Stops Cellular Demethylation of H3K4me3 at Transcription Start Sites and Proliferation of MM1S Myeloma Cells. Cell. Chem. Biol. 2017, 24, 371-380. [CrossRef]

145. Cascella, B.; Lee, S.G.; Singh, S.; Jez, J.M.; Mirica, L.M. The small molecule JIB-04 disrupts $\mathrm{O}_{2}$ binding in the Fe-dependent histone demethylase KDM4A/JMJD2A. Chem. Commun. 2017, 53, 2174-2177. [CrossRef]

146. Gerken, P.A.; Wolstenhulme, J.R.; Tumber, A.; Hatch, S.B.; Zhang, Y.; Muller, S.; Chandler, S.A.; Mair, B.; Li, F.; Nijman, S.M.B.; et al. Discovery of a Highly Selective Cell-Active Inhibitor of the Histone Lysine Demethylases KDM2/7. Angew. Chem. Int. Ed. Engl. 2017, 56, 15555-15559. [CrossRef]

147. Kawamura, A.; Munzel, M.; Kojima, T.; Yapp, C.; Bhushan, B.; Goto, Y.; Tumber, A.; Katoh, T.; King, O.N.; Passioura, T.; et al. Highly selective inhibition of histone demethylases by de novo macrocyclic peptides. Nat. Commun. 2017, 8, 14773. [CrossRef]

148. Jambhekar, A.; Anastas, J.N.; Shi, Y. Histone Lysine Demethylase Inhibitors. Cold Spring Harb. Perspect. Med. 2017, 7, a026484. [CrossRef]

149. Chowdhury, R.; Yeoh, K.K.; Tian, Y.M.; Hillringhaus, L.; Bagg, E.A.; Rose, N.R.; Leung, I.K.; Li, X.S.; Woon, E.C.; Yang, M.; et al. The oncometabolite 2-hydroxyglutarate inhibits histone lysine demethylases. EMBO Rep. 2011, 12, 463-469. [CrossRef]

150. Lu, C.; Ward, P.S.; Kapoor, G.S.; Rohle, D.; Turcan, S.; Abdel-Wahab, O.; Edwards, C.R.; Khanin, R.; Figueroa, M.E.; Melnick, A.; et al. IDH mutation impairs histone demethylation and results in a block to cell differentiation. Nature 2012, 483, 474-478. [CrossRef]

151. Waitkus, M.S.; Diplas, B.H.; Yan, H. Biological Role and Therapeutic Potential of IDH Mutations in Cancer. Cancer Cell 2018, 34, 186-195. [CrossRef]

152. Ward, P.S.; Cross, J.R.; Lu, C.; Weigert, O.; Abel-Wahab, O.; Levine, R.L.; Weinstock, D.M.; Sharp, K.A.; Thompson, C.B. Identification of additional IDH mutations associated with oncometabolite R(-)-2hydroxyglutarate production. Oncogene 2012, 31, 2491-2498. [CrossRef]

153. Laukka, T.; Myllykoski, M.; Looper, R.E.; Koivunen, P. Cancer-associated 2-oxoglutarate analogues modify histone methylation by inhibiting histone lysine demethylases. J. Mol. Biol. 2018, 430, 3081-3092. [CrossRef]

154. Sulkowski, P.L.; Corso, C.D.; Robinson, N.D.; Scanlon, S.E.; Purshouse, K.R.; Bai, H.; Liu, Y.; Sundaram, R.K.; Hegan, D.C.; Fons, N.R.; et al. 2-Hydroxyglutarate produced by neomorphic IDH mutations suppresses homologous recombination and induces PARP inhibitor sensitivity. Sci. Transl. Med. 2017, 9, eaal2463. [CrossRef]

155. Sulkowski, P.L.; Sundaram, R.K.; Oeck, S.; Corso, C.D.; Liu, Y.; Noorbakhsh, S.; Niger, M.; Boeke, M.; Ueno, D.; Kalathil, A.N.; et al. Krebs-cycle-deficient hereditary cancer syndromes are defined by defects in homologous-recombination DNA repair. Nat. Genet. 2018, 50, 1086-1092. [CrossRef] 